UDC693.546

\title{
DYNAMIC BALANCING OF ROLLER FORMING UNIT DRIVE
}

\author{
V.S. Loveikin ${ }^{1}$, \\ Doctor of Technical Science, Professor \\ K.I. Pochka ${ }^{2}$, \\ Doctor of Technical Science, Professor \\ M.O. Prystailo ${ }^{2}$, \\ Candidate of Science (Engineering), Associate Professor \\ M.M. Balaka ${ }^{2}$, \\ Candidate of Science (Engineering) \\ O.B. Pochka ${ }^{2}$ \\ ${ }^{1}$ National University of Life and Environmental Sciences of Ukraine \\ 15, Heroiv Oborony St., Kyiv, Ukraine, 03041 \\ ${ }^{2}$ Kyiv National University of Construction and Architecture \\ 31, Povitroflotsky Ave., Kyiv, Ukraine, 03037
}

DOI: $10.32347 / 2410-2547.2021 .107 .140-158$

The dynamic balancing of the drive mechanism is considered for a roller forming unit with balanced drive. Two dynamic balancing problems are solved in the simulation process of the drive mechanism balancing: the inertia forces balancing which applied in the masses centers of the motion links, and the torque balancing which reduced to rotation axis of the drive shaft, that arise from the inertia forces action. The drive mechanism imbalance is estimated by the maximum and root-mean-square values of the total inertia force and total torque from the inertia forces action, the dimensionless coefficients, which express the root-mean-square values ratio of the total inertia force and inertia forces, that act on each trolley, and the root-mean-square values ratio of the moment from the inertia forces action of the whole mechanism and moment components from the inertia forces action of the individual elements.

Keywords: roller forming unit, drive mechanism, inertia force, moment, balancing.

Introduction. In the existing units for surface compacting of products from building mixtures the slider-crank or hydraulic drive at reciprocating motion of the forming trolley with the compaction rollers is used [1-4].During continuous start-stop modes, considerable dynamic loads appear both in the drive mechanism and forming trolley elements, which may lead to the premature failure of the unit.

Analysis of publications. In the existing theoretical and experimental studies of roller forming units designed for forming products from building mixtures, their design parameters and productivity are substantiated [1-4]. At the same time, insufficient attention is paid to the study of the existing dynamic loads [5-14] and motion modes [15-18], which greatly impact both the operation of the unit and the quality of the finished products. During continuous start-stop modes of the forming trolleys motion, in the unit elements, except gravity forces and resistance forces, inertia forces appear also 
[5-14], which create additional loads on the drive mechanism. Therefore, the drive mechanism balancing task of roller forming machines is actual.

Purpose of the paper. The purpose of this paper is the drive mechanism dynamic balancing of the roller forming unit with balanced drive.

Research results. In order to reduce energy consumption in roller forming machines, a design of the roller forming unit $[19,20]$ wasproposedtoprovidethecompactionofproductsfrombuildingmixturesonasingl etechnologicalline. It consists of four forming trolleys, located parallel to each other on one side of the drive shaft, which are set in reciprocating motion from the one drive. It is composed of four slider-crank mechanisms, whose cranks are rigidly fixed on one drive shaft and shifted to each other at the angle $\Delta \varphi=90^{\circ}$ (Fig. 1 (a)).

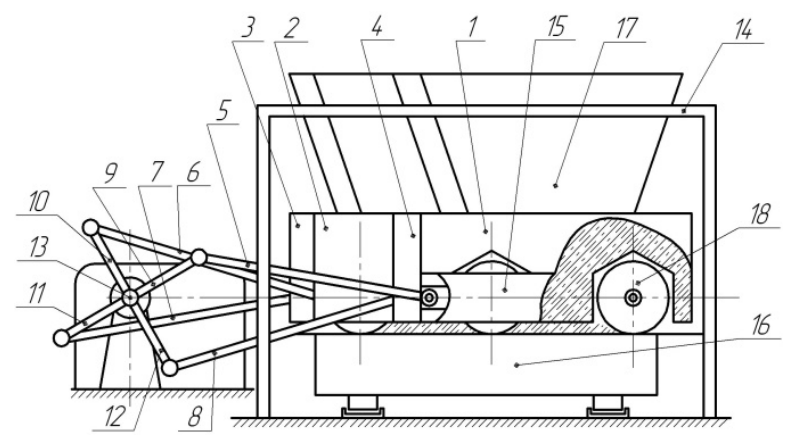

(a)

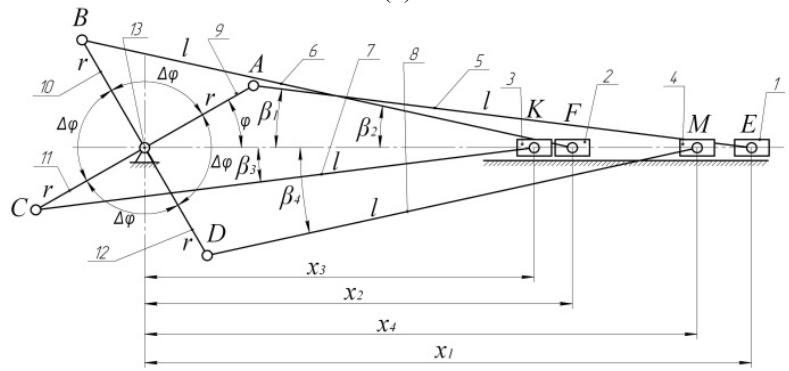

(b)

Fig. 1. Roller forming unit with balanced drive (a) and its kinematic scheme (b)

Each of the forming trolleys 1, 2, 3 and 4 is mounted on the gantry 14 and performs reciprocating motion in the guide rails 15 over the cavity of the form 16. The forming trolley 1 consists of the feeding hopper 17 and coaxial sections of the compaction rollers 18 . The other three trolleys have the same design. The trolleys $1,2,3$ and 4 with distributive hoppers are set into reciprocating motion by a drive made in the form of four slider-crank mechanisms, whose cranks 9, 10, 11 and 12 are rigidly fixed on one drive shaft 13 and shifted to each other at the angle $\Delta \varphi=90^{\circ}$. The connecting rods 5, 6, 7 and 8 are hinged to the forming trolleys 1,2, 3 and 4, while their other ends are 
connected to the cranks $9,10,11$ and 12 . Such a design of the roller forming unit makes it possible to reduce the dynamic loads in the drive elements, extra devastating loads on the frame structure and, accordingly, to increase the unit durability as a whole.

Fig. 1 (b) shows a kinematic scheme of the roller forming unit with balanced drive for compacting reinforced concrete products on a single technological line. This kinematic scheme contains the such symbols: $r-$ cranks radius $9,10,11$ and $12 ; l$ - length of connecting rods 5, 6, 7 and $8 ; \varphi$ - angular coordinate of the crank position for the first trolley; $\Delta \varphi$ - cranks displacement angle 9-10, 10-11,11-12 and 12-9 between them; $x_{1}, x_{2}, x_{3}$ and $x_{4}$-coordinates of the trolleys masses centers $1,2,3$ and $4 ; \beta_{1}, \beta_{2}, \beta_{3}$ and $\beta_{4}$ - angular coordinates that determine the connecting rods position of the first, second, third and fourth trolleys relative to the horizontal.

We determine the coordinates of the trolleys masses centers $1,2,3$ and 4 (Fig. 1) [18]:

$$
\begin{gathered}
x_{1}=r \cdot \cos \varphi+l \cdot \cos \beta_{1} ; \quad x_{2}=r \cdot \cos (\varphi+\Delta \varphi)+l \cdot \cos \beta_{2} ; \\
x_{3}=r \cdot \cos (\varphi+2 \Delta \varphi)+l \cdot \cos \beta_{3} ; \quad x_{4}=r \cdot \cos (\varphi+3 \Delta \varphi)+l \cdot \cos \beta_{4} .
\end{gathered}
$$

As the angles $\beta_{1}, \beta_{2}, \beta_{3}$ and $\beta_{4}$ are unknown, they can be determined dependent on the length of connecting rod $l$, the crank radius $r$, the angular coordinate of crank $\varphi$ and the cranks displacement angle $\Delta \varphi[18]$ :

$$
\begin{gathered}
r \cdot \sin \varphi=l \cdot \sin \beta_{1} \rightarrow \sin \beta_{1}=\frac{r}{l} \cdot \sin \varphi ; \\
r \cdot \sin (\varphi+\Delta \varphi)=l \cdot \sin \beta_{2} \rightarrow \sin \beta_{2}=\frac{r}{l} \cdot \sin (\varphi+\Delta \varphi) ; \\
r \cdot \sin (\varphi+2 \Delta \varphi)=l \cdot \sin \beta_{3} \rightarrow \sin \beta_{3}=\frac{r}{l} \cdot \sin (\varphi+2 \Delta \varphi) ; \\
r \cdot \sin (\varphi+3 \Delta \varphi)=l \cdot \sin \beta_{4} \rightarrow \sin \beta_{4}=\frac{r}{l} \cdot \sin (\varphi+3 \Delta \varphi) .
\end{gathered}
$$

From here:

$$
\begin{gathered}
\cos \beta_{1}=\sqrt{1-\sin ^{2} \beta_{1}}=\sqrt{1-\frac{r^{2}}{l^{2}} \cdot \sin ^{2} \varphi ;} \\
\cos \beta_{2}=\sqrt{1-\sin ^{2} \beta_{2}}=\sqrt{1-\frac{r^{2}}{l^{2}} \cdot \sin ^{2}(\varphi+\Delta \varphi)} ; \\
\cos \beta_{3}=\sqrt{1-\sin ^{2} \beta_{3}}=\sqrt{1-\frac{r^{2}}{l^{2}} \cdot \sin ^{2}(\varphi+2 \Delta \varphi)} ; \\
\cos \beta_{4}=\sqrt{1-\sin ^{2} \beta_{4}}=\sqrt{1-\frac{r^{2}}{l^{2}} \cdot \sin ^{2}(\varphi+3 \Delta \varphi)} .
\end{gathered}
$$


Then coordinates of the trolleys masses centers:

$$
\begin{gathered}
x_{1}=r \cdot \cos \varphi+l \cdot \sqrt{1-\frac{r^{2}}{l^{2}} \cdot \sin ^{2} \varphi} ; \\
x_{2}=r \cdot \cos (\varphi+\Delta \varphi)+l \cdot \sqrt{1-\frac{r^{2}}{l^{2}} \cdot \sin ^{2}(\varphi+\Delta \varphi)} ; \\
x_{4}=r \cdot \cos (\varphi+3 \Delta \varphi)+l \cdot \sqrt{1-\frac{r^{2}}{l^{2}} \cdot \sin ^{2}(\varphi+3 \Delta \varphi)} .
\end{gathered}
$$

From the expressions (2) we obtain the change functions of the masses centers velocity for the forming trolleys:

$$
\dot{x}_{1}=\dot{\varphi} \cdot \frac{\partial x_{1}}{\partial \varphi} ; \quad \dot{x}_{2}=\dot{\varphi} \cdot \frac{\partial x_{2}}{\partial \varphi} ; \quad \dot{x}_{3}=\dot{\varphi} \cdot \frac{\partial x_{3}}{\partial \varphi} ; \quad \dot{x}_{4}=\dot{\varphi} \cdot \frac{\partial x_{4}}{\partial \varphi},
$$

where $\dot{\varphi}=\omega-$ cranks angular velocity; $\frac{\partial x_{1}}{\partial \varphi}, \frac{\partial x_{2}}{\partial \varphi}, \frac{\partial x_{3}}{\partial \varphi}, \frac{\partial x_{4}}{\partial \varphi}-$ the first transfer functions of the trolleys masses centers $1,2,3$ and 4 , which are defined by the following expressions [18]:

$$
\begin{gathered}
\frac{\partial x_{1}}{\partial \varphi}=-r \cdot \sin \varphi \cdot\left(1+\frac{r}{l} \cdot \frac{\cos \varphi}{\sqrt{1-\left(r^{2} / l^{2}\right) \cdot \sin ^{2} \varphi}}\right) ; \\
\frac{\partial x_{2}}{\partial \varphi}=-r \cdot \sin (\varphi+\Delta \varphi) \cdot\left(1+\frac{r}{l} \cdot \frac{\cos (\varphi+\Delta \varphi)}{\sqrt{1-\left(r^{2} / l^{2}\right) \cdot \sin ^{2}(\varphi+\Delta \varphi)}}\right) ; \\
\frac{\partial x_{3}}{\partial \varphi}=-r \cdot \sin (\varphi+2 \Delta \varphi) \cdot\left(1+\frac{r}{l} \cdot \frac{\cos (\varphi+2 \Delta \varphi)}{\sqrt{1-\left(r^{2} / l^{2}\right) \cdot \sin ^{2}(\varphi+2 \Delta \varphi)}}\right) ; \\
\frac{\partial x_{4}}{\partial \varphi}=-r \cdot \sin (\varphi+3 \Delta \varphi) \cdot\left(1+\frac{r}{l} \cdot \frac{\cos (\varphi+3 \Delta \varphi)}{\sqrt{1-\left(r^{2} / l^{2}\right) \cdot \sin ^{2}(\varphi+3 \Delta \varphi)}}\right) .
\end{gathered}
$$

The change functions of the linear accelerations for trolleys masses centers $1,2,3$ and 4 are determined by the dependences:

$$
\begin{aligned}
& \ddot{x}_{1}=\ddot{\varphi} \cdot \frac{\partial x_{1}}{\partial \varphi}+\dot{\varphi}^{2} \cdot \frac{\partial^{2} x_{1}}{\partial \varphi^{2}} ; \quad \ddot{x}_{2}=\ddot{\varphi} \cdot \frac{\partial x_{2}}{\partial \varphi}+\dot{\varphi}^{2} \cdot \frac{\partial^{2} x_{2}}{\partial \varphi^{2}} ; \\
& \ddot{x}_{3}=\ddot{\varphi} \cdot \frac{\partial x_{3}}{\partial \varphi}+\dot{\varphi}^{2} \cdot \frac{\partial^{2} x_{3}}{\partial \varphi^{2}} ; \quad \ddot{x}_{4}=\ddot{\varphi} \cdot \frac{\partial x_{4}}{\partial \varphi}+\dot{\varphi}^{2} \cdot \frac{\partial^{2} x_{4}}{\partial \varphi^{2}},
\end{aligned}
$$

where $\ddot{\varphi}=\varepsilon-$ cranks angular acceleration; $\frac{\partial^{2} x_{1}}{\partial \varphi^{2}}, \frac{\partial^{2} x_{2}}{\partial \varphi^{2}}, \frac{\partial^{2} x_{3}}{\partial \varphi^{2}}, \frac{\partial^{2} x_{4}}{\partial \varphi^{2}}-$ the second transfer functions of the trolleys masses centers $1,2,3$ and 4 , which are defined by the following expressions [18]: 
$\frac{\partial^{2} x_{1}}{\partial \varphi^{2}}=-r \cdot\left[\cos \varphi \cdot\left(1+\frac{r}{l} \frac{\cos \varphi}{\sqrt{1-\frac{r^{2}}{l^{2}} \cdot \sin ^{2} \varphi}}\right]+\frac{r}{l} \sin ^{2} \varphi \frac{\left(\frac{r^{2}}{l^{2}} \cdot \cos ^{2} \varphi-1\right)}{\left(1-\frac{r^{2}}{l^{2}} \cdot \sin ^{2} \varphi\right)^{\frac{3}{2}}}\right]$

$\frac{\partial^{2} x_{2}}{\partial \varphi^{2}}=-r \cdot\left[\begin{array}{c}\cos (\varphi+\Delta \varphi) \cdot\left(1+\frac{r}{l} \cdot \frac{\cos (\varphi+\Delta \varphi)}{\sqrt{1-\frac{r^{2}}{l^{2}} \cdot \sin ^{2}(\varphi+\Delta \varphi)}}\right. \\ \frac{r}{l} \cdot \sin ^{2}(\varphi+\Delta \varphi) \cdot \frac{\left(\frac{r^{2}}{l^{2}} \cdot \cos ^{2}(\varphi+\Delta \varphi)-1\right)}{\left(1-\frac{r^{2}}{l^{2}} \cdot \sin ^{2}(\varphi+\Delta \varphi)\right)^{\frac{3}{2}}}\end{array}\right]$

$\frac{\partial^{2} x_{3}}{\partial \varphi^{2}}=-r \cdot\left[\begin{array}{c}\cos (\varphi+2 \Delta \varphi) \cdot\left(1+\frac{r}{l} \cdot \frac{\cos (\varphi+2 \Delta \varphi)}{\sqrt{1-\frac{r^{2}}{l^{2}} \cdot \sin ^{2}(\varphi+2 \Delta \varphi)}}\right. \\ \frac{r}{l} \cdot \sin ^{2}(\varphi+2 \Delta \varphi) \cdot \frac{\left(\frac{r^{2}}{l^{2}} \cdot \cos ^{2}(\varphi+2 \Delta \varphi)-1\right)}{\left(1-\frac{r^{2}}{l^{2}} \cdot \sin ^{2}(\varphi+2 \Delta \varphi)\right)^{\frac{3}{2}}}\end{array}\right] ;$

$\frac{\partial^{2} x_{4}}{\partial \varphi^{2}}=-r \cdot\left[\begin{array}{c}\cos (\varphi+3 \Delta \varphi) \cdot\left(1+\frac{r}{l} \cdot \frac{\cos (\varphi+3 \Delta \varphi)}{\sqrt{1-\frac{r^{2}}{l^{2}} \cdot \sin ^{2}(\varphi+3 \Delta \varphi)}}\right) \\ \frac{r}{l} \cdot \sin ^{2}(\varphi+3 \Delta \varphi) \cdot \frac{\left(\frac{r^{2}}{l^{2}} \cdot \cos ^{2}(\varphi+3 \Delta \varphi)-1\right)}{\left(1-\frac{r^{2}}{l^{2}} \cdot \sin ^{2}(\varphi+3 \Delta \varphi)\right)^{\frac{3}{2}}}\end{array}\right]$. 
The kinetic energy of the whole system is defined as the kinetic energies total of the drive mechanism components and the forming trolleys components:

$$
\begin{aligned}
& T=\frac{J_{d r} \dot{\varphi}^{2}}{2}+\frac{m_{1} \dot{x}_{1}^{2}}{2}+\frac{m_{2} \cdot \dot{x}_{2}^{2}}{2}+\frac{m_{3} \dot{x}_{3}^{2}}{2}+\frac{m_{4} \dot{x}_{4}^{2}}{2}+\frac{J_{S_{5}} \dot{\beta}_{1}^{2}}{2}+\frac{m_{5}\left(\dot{x}_{S_{5}}^{2}+\dot{y}_{S_{5}}^{2}\right)}{2}+ \\
& +\frac{J_{S_{6}} \dot{\beta}_{2}^{2}}{2}+\frac{m_{6}\left(\dot{x}_{S_{6}}^{2}+\dot{y}_{S_{6}}^{2}\right)}{2}+\frac{J_{S_{7}} \dot{\beta}_{3}^{2}}{2}+\frac{m_{7}\left(\dot{x}_{S_{7}}^{2}+\dot{y}_{S_{7}}^{2}\right)}{2}+\frac{J_{S_{8}} \dot{\beta}_{4}^{2}}{2}+\frac{m_{8}\left(\dot{x}_{S_{8}}^{2}+\dot{y}_{S_{8}}^{2}\right)}{2},
\end{aligned}
$$

where $J_{d r}$ - inertia moment of the drive mechanism, reduced to the driveshaft rotation axis (taking into account the motorrotor, transmission and couplings); $m_{1}, m_{2}, m_{3}$ and $m_{4}$ - forming trolleys masses 1,2, 3 and 4 (forming trolleys masses are equal $\left.m_{1}=m_{2}=m_{3}=m_{4}=m\right) ; m_{5}, m_{6}, m_{7}, m_{8}, J_{S_{5}}, J_{S_{6}}$, $J_{S_{7}}$ and $J_{S_{8}}$ - connecting rods masses $5,6,7,8$, and theirnative inertia moments relative to the masses centers; $\dot{\beta}_{1}, \dot{\beta}_{2}, \dot{\beta}_{3}$ and $\dot{\beta}_{4}$ - angular velocities of connecting rods 5, 6, 7 and 8; $\dot{x}_{S_{5}}, \dot{y}_{S_{5}}, \dot{x}_{S_{6}}, \dot{y}_{S_{6}}, \dot{x}_{S_{7}}, \dot{y}_{S_{7}}, \dot{x}_{S_{8}}$ and $\dot{y}_{S_{8}}-$ linear velocities of the connecting rods masses centers $5,6,7$ and 8 .

As the connecting rods masses 5, 6, 7 and 8 are much smaller than the forming trolleys masses $1,2,3$ and 4 , we can neglect these masses and, accordingly, neglect the kinetic energy of these connecting rods.

Then the kinetic energy value of roller forming unit will have the look

$$
\begin{aligned}
& T=\frac{J_{d r} \cdot \dot{\varphi}^{2}}{2}+\frac{m \cdot \dot{x}_{1}^{2}}{2}+\frac{m \cdot \dot{x}_{2}^{2}}{2}+\frac{m \cdot \dot{x}_{3}^{2}}{2}+\frac{m \cdot \dot{x}_{4}^{2}}{2}= \\
& =\frac{J_{d r} \cdot \dot{\varphi}^{2}}{2}+\frac{m}{2} \cdot\left[\dot{\varphi}^{2} \cdot\left(\frac{\partial x_{1}}{\partial \varphi}\right)^{2}+\dot{\varphi}^{2} \cdot\left(\frac{\partial x_{2}}{\partial \varphi}\right)^{2}+\dot{\varphi}^{2} \cdot\left(\frac{\partial x_{3}}{\partial \varphi}\right)^{2}+\dot{\varphi}^{2} \cdot\left(\frac{\partial x_{4}}{\partial \varphi}\right)^{2}\right]
\end{aligned}
$$

or

$$
T=\frac{\dot{\varphi}^{2}}{2} \cdot\left\{J_{d r}+m \cdot\left[\left(\frac{\partial x_{1}}{\partial \varphi}\right)^{2}+\left(\frac{\partial x_{2}}{\partial \varphi}\right)^{2}+\left(\frac{\partial x_{3}}{\partial \varphi}\right)^{2}+\left(\frac{\partial x_{4}}{\partial \varphi}\right)^{2}\right]\right\} .
$$

We make up the motion equation of the roller forming unit.To do this, we use the second-order Lagrange equation

$$
\frac{d}{d t} \frac{\partial T}{\partial \dot{\varphi}}-\frac{\partial T}{\partial \varphi}=Q_{\varphi},
$$

where $t$ - time; $\varphi$ - angular coordinate of the crank position, which taken as the generalized coordinate; $Q_{\varphi}$ - generalized force, that corresponds to this generalized coordinate.

The generalized force is determined by the dependence:

$$
Q_{\varphi}=M_{d r}-F_{r e s 1} \cdot \frac{\partial x_{1}}{\partial \varphi}-F_{r e s 2} \cdot \frac{\partial x_{2}}{\partial \varphi}-F_{r e s} \cdot \frac{\partial x_{3}}{\partial \varphi}-F_{r e s} \cdot \frac{\partial x_{4}}{\partial \varphi} .
$$


Here $F_{r e s 1}, F_{r e s 2}, F_{r e s 3}$ and $F_{\text {res } 4}$ - resistance forces to the shift of the forming trolleys 1, 2, 3 and 4; $M_{d r}$ - motor driving moment, reduced to the crank rotation axis, which is determined by the Kloss formula:

$$
\begin{gathered}
M_{d r}=\frac{2 \cdot M_{\text {crit }}}{\frac{s}{s_{\text {crit }}}+\frac{s_{\text {crit }}}{s}} \cdot u \cdot \eta ; \\
s=1-\frac{\omega}{\omega_{0}}=1-\frac{\dot{\varphi} \cdot u}{\omega_{0}} ; \\
s_{\text {crit }}=1-\frac{\omega_{\text {crit }}}{\omega_{0}},
\end{gathered}
$$

where $M_{\text {crit }}$ - critical moment on the motorshaft; $s$ and $s_{c r i t}$ - lip and its critical value; $\omega$ and $\omega_{0}$ - angular velocity of the motor rotor and its synchronous value; $u$ - transmission gear ratio from the motor to the drive shaft; $\eta$ - drive mechanism efficiency.

After dependences substitution (9) and (11)...(14) into equation (10), we obtain:

$$
\begin{aligned}
& \frac{\partial T}{\partial \varphi}=\dot{\varphi}^{2} \cdot m \cdot\left(\frac{\partial x_{1}}{\partial \varphi} \cdot \frac{\partial^{2} x_{1}}{\partial \varphi^{2}}+\frac{\partial x_{2}}{\partial \varphi} \cdot \frac{\partial^{2} x_{2}}{\partial \varphi^{2}}+\frac{\partial x_{3}}{\partial \varphi} \cdot \frac{\partial^{2} x_{3}}{\partial \varphi^{2}}+\frac{\partial x_{4}}{\partial \varphi} \cdot \frac{\partial^{2} x_{4}}{\partial \varphi^{2}}\right) ; \\
& \frac{\partial T}{\partial \dot{\varphi}}=\dot{\varphi} \cdot\left\{J_{d r}+m \cdot\left[\left(\frac{\partial x_{1}}{\partial \varphi}\right)^{2}+\left(\frac{\partial x_{2}}{\partial \varphi}\right)^{2}+\left(\frac{\partial x_{3}}{\partial \varphi}\right)^{2}+\left(\frac{\partial x_{4}}{\partial \varphi}\right)^{2}\right]\right\} ; \\
& \frac{d}{d t} \frac{\partial T}{\partial \dot{\varphi}}=\ddot{\varphi} \cdot\left\{J_{d r}+m \cdot\left[\left(\frac{\partial x_{1}}{\partial \varphi}\right)^{2}+\left(\frac{\partial x_{2}}{\partial \varphi}\right)^{2}+\left(\frac{\partial x_{3}}{\partial \varphi}\right)^{2}+\left(\frac{\partial x_{4}}{\partial \varphi}\right)^{2}\right]\right\}+ \\
& +2 \cdot \dot{\varphi}^{2} \cdot m \cdot\left(\frac{\partial x_{1}}{\partial \varphi} \cdot \frac{\partial^{2} x_{1}}{\partial \varphi^{2}}+\frac{\partial x_{2}}{\partial \varphi} \cdot \frac{\partial^{2} x_{2}}{\partial \varphi^{2}}+\frac{\partial x_{3}}{\partial \varphi} \cdot \frac{\partial^{2} x_{3}}{\partial \varphi^{2}}+\frac{\partial x_{4}}{\partial \varphi} \cdot \frac{\partial^{2} x_{4}}{\partial \varphi^{2}}\right) \text {; } \\
& \ddot{\varphi} \cdot\left\{J_{d r}+m \cdot\left[\left(\frac{\partial x_{1}}{\partial \varphi}\right)^{2}+\left(\frac{\partial x_{2}}{\partial \varphi}\right)^{2}+\left(\frac{\partial x_{3}}{\partial \varphi}\right)^{2}+\left(\frac{\partial x_{4}}{\partial \varphi}\right)^{2}\right]\right\}+ \\
& +2 \cdot \dot{\varphi}^{2} \cdot m \cdot\left(\frac{\partial x_{1}}{\partial \varphi} \cdot \frac{\partial^{2} x_{1}}{\partial \varphi^{2}}+\frac{\partial x_{2}}{\partial \varphi} \cdot \frac{\partial^{2} x_{2}}{\partial \varphi^{2}}+\frac{\partial x_{3}}{\partial \varphi} \cdot \frac{\partial^{2} x_{3}}{\partial \varphi^{2}}+\frac{\partial x_{4}}{\partial \varphi} \cdot \frac{\partial^{2} x_{4}}{\partial \varphi^{2}}\right)= \\
& =\frac{2 \cdot M_{\text {crit }}}{1-\frac{\dot{\varphi} \cdot u}{\omega_{0}} 1-\frac{\omega_{\text {crit }}}{\omega_{0}}} \cdot u \cdot \eta-F_{\text {res } 1} \frac{\partial x_{1}}{\partial \varphi}-F_{\text {res } 2} \frac{\partial x_{2}}{\partial \varphi}-F_{r e s} \frac{\partial x_{3}}{\partial \varphi}-F_{r e s} \frac{\partial x_{4}}{\partial \varphi} \text {. } \\
& \frac{\omega_{0}}{1-\frac{\omega_{c r i t}}{\omega_{0}}}+\frac{\omega_{0}}{1-\frac{\dot{\varphi} \cdot u}{\omega_{0}}}
\end{aligned}
$$


The equation is a second-order nonlinear equation that must be solved numerically. As a result of solving equation (15) we obtain dependences [16]:

$$
\varphi=\varphi(t) ; \quad \dot{\varphi}=\dot{\varphi}(t) ; \quad \ddot{\varphi}=\ddot{\varphi}(t) .
$$

Dynamic analysis of high-speed mechanisms, which includes the roller forming unit, is requires the two problems solution of the dynamic balancing:

1) the inertia forces balancing, which applied in the masses centers of the motion links;

2) the torque balancing, which reduced to rotation axis of the drive shaft, that arise from the inertia forces action.

To the first problem solve, it's necessary that the masses center of the motion parts for roller forming unit (forming trolleys) is not shifted. That is, the condition must be met for the roller forming unit, the trolleys of which move along the axis $x$ :

$$
x_{c}=\frac{m_{1} \cdot x_{1}+m_{2} \cdot x_{2}+m_{3} \cdot x_{3}+m_{4} \cdot x_{4}}{m_{1}+m_{2}+m_{3}+m_{4}}=\text { const . }
$$

The dependence (17) is differentiated twice in time, we obtain:

$$
\ddot{x}_{c}=\frac{m_{1} \cdot \ddot{x}_{1}+m_{2} \cdot \ddot{x}_{2}+m_{3} \cdot \ddot{x}_{3}+m_{4} \cdot \ddot{x}_{4}}{m_{1}+m_{2}+m_{3}+m_{4}}=0 .
$$

The expression (18) can be written as follows:

$$
\begin{aligned}
& F_{i c}=m_{1} \cdot \ddot{x}_{1}+m_{2} \cdot \ddot{x}_{2}+m_{3} \cdot \ddot{x}_{3}+m_{4} \cdot \ddot{x}_{4}= \\
& =m_{1}\left(\ddot{\varphi} \cdot \frac{\partial x_{1}}{\partial}+\dot{\varphi}^{2} \cdot \frac{\partial^{2} x_{1}}{\partial \varphi^{2}}\right)+m_{2}\left(\ddot{\varphi} \cdot \frac{\partial x_{2}}{\partial \varphi}+\dot{\varphi}^{2} \cdot \frac{\partial^{2} x_{2}}{\partial \varphi^{2}}\right)+ \\
& +m_{3}\left(\ddot{\varphi} \cdot \frac{\partial x_{3}}{\partial \varphi}+\dot{\varphi}^{2} \cdot \frac{\partial^{2} x_{3}}{\partial \varphi^{2}}\right)+m_{4}\left(\ddot{\varphi} \cdot \frac{\partial x_{4}}{\partial \varphi}+\dot{\varphi}^{2} \cdot \frac{\partial^{2} x_{4}}{\partial \varphi^{2}}\right)=0,
\end{aligned}
$$

where $F_{i c}$ - total inertia force, reduced to the masses center of the motion parts for roller forming unit from the inertia forces action of the individual trolleys.

Given that $m_{1}=m_{2}=m_{3}=m_{4}=m$, we will have:

$$
F_{i c}=m\left[\ddot{\varphi}\left(\frac{\partial x_{1}}{\partial \varphi}+\frac{\partial x_{2}}{\partial \varphi}+\frac{\partial x_{3}}{\partial \varphi}+\frac{\partial x_{4}}{\partial \varphi}\right)+\dot{\varphi}^{2}\left(\frac{\partial^{2} x_{1}}{\partial \varphi^{2}}+\frac{\partial^{2} x_{2}}{\partial \varphi^{2}}+\frac{\partial^{2} x_{3}}{\partial \varphi^{2}}+\frac{\partial^{2} x_{4}}{\partial \varphi^{2}}\right)\right]=0 .
$$

There is the inertia forces imbalance, if the condition (19) or (20) is not satisfied. The criterion for this imbalance may be the total inertia forces value of the roller forming unit:

$$
F_{i c}=m \cdot\left[\begin{array}{l}
\ddot{\varphi} \cdot\left(\frac{\partial x_{1}}{\partial \varphi}+\frac{\partial x_{2}}{\partial \varphi}+\frac{\partial x_{3}}{\partial \varphi}+\frac{\partial x_{4}}{\partial \varphi}\right)+ \\
+\dot{\varphi}^{2} \cdot\left(\frac{\partial^{2} x_{1}}{\partial \varphi^{2}}+\frac{\partial^{2} x_{2}}{\partial \varphi^{2}}+\frac{\partial^{2} x_{3}}{\partial \varphi^{2}}+\frac{\partial^{2} x_{4}}{\partial \varphi^{2}}\right)
\end{array}\right] .
$$

The inertia forces non-uniformity for one cycle of the roller forming unit motion (one crank rotation) can be estimated by the inertia force maximum 
value $F_{i c \max }$, reduced to the masses center, or its root-mean-square value, which is determined by the dependence:

$$
\bar{F}_{i c}=\sqrt{\frac{1}{t_{1}} \int_{0}^{t_{1}} F_{i c}^{2} d t}=\sqrt{\frac{m^{2}}{t_{1}} \int_{0}^{t_{1}}\left[\begin{array}{l}
\ddot{\varphi}\left(\frac{\partial x_{1}}{\partial \varphi}+\frac{\partial x_{2}}{\partial \varphi}+\frac{\partial x_{3}}{\partial \varphi}+\frac{\partial x_{4}}{\partial \varphi}\right)+ \\
\left.+\dot{\varphi}^{2}\left(\frac{\partial^{2} x_{1}}{\partial \varphi^{2}}+\frac{\partial^{2} x_{2}}{\partial \varphi^{2}}+\frac{\partial^{2} x_{3}}{\partial \varphi^{2}}+\frac{\partial^{2} x_{4}}{\partial \varphi^{2}}\right)\right]^{2}
\end{array}\right]}
$$

where $t_{1}=\frac{2 \cdot \pi}{\omega_{\text {nom }}}-$ time cycle of the roller forming unit; $\omega_{\text {nom }}-$ angular velocity nominal value of the drive shaft for roller forming unit.

In some cases, the inertia forces imbalance on the forming unit links is advisable to estimate by the dimensionless coefficient. It can be represented by the root-mean-square values ratio, reduced to the masses center of the total inertia force and the inertia forces on each trolley.

The dimensionless coefficient can be represented as follows:

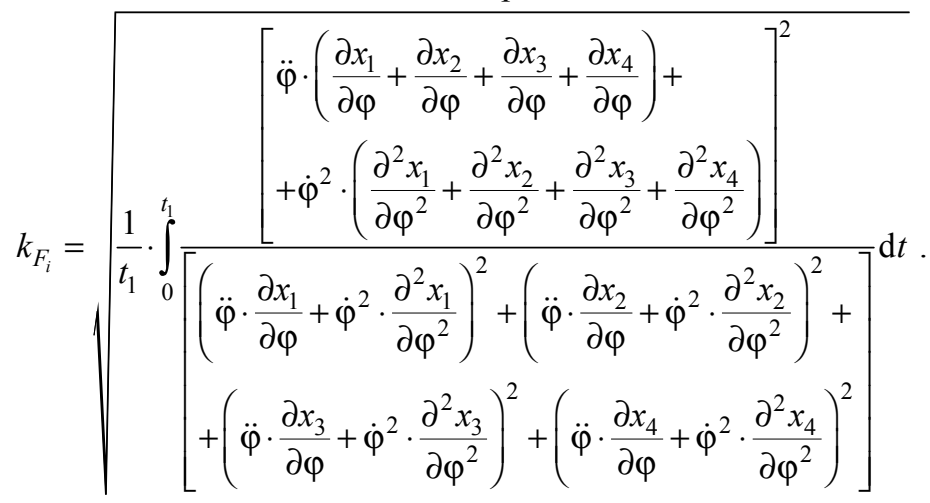

We will write down the necessary condition to ensure the torque balance of the drive shaft from the inertia forces action:

$$
T=\text { const } \text { or } \frac{\partial T}{\partial \varphi}=0 \text {. }
$$

The torque imbalance of the drive shaft from the inertia forces action there is, if the condition (24) is not fulfilled. The imbalance criterion can be the torque value, which is determined by the dependence:

$$
\begin{aligned}
& M_{i}=\frac{\partial T}{\partial \varphi}=m\left(\dot{x}_{1} \frac{\partial \dot{x}_{1}}{\partial \varphi}+\dot{x}_{2} \frac{\partial \dot{x}_{2}}{\partial \varphi}+\dot{x}_{3} \frac{\partial \dot{x}_{3}}{\partial \varphi}+\dot{x}_{4} \frac{\partial \dot{x}_{4}}{\partial \varphi}\right)= \\
& =m \cdot \dot{\varphi}^{2}\left(\frac{\partial x_{1}}{\partial \varphi} \frac{\partial^{2} x_{1}}{\partial \varphi^{2}}+\frac{\partial x_{2}}{\partial \varphi} \frac{\partial^{2} x_{2}}{\partial \varphi^{2}}+\frac{\partial x_{3}}{\partial \varphi} \frac{\partial^{2} x_{3}}{\partial \varphi^{2}}+\frac{\partial x_{4}}{\partial \varphi} \frac{\partial^{2} x_{4}}{\partial \varphi^{2}}\right) .
\end{aligned}
$$


The torque imbalance of the drive shaft from the inertia forces action can be estimated by its maximum value $M_{i \max }$ in one cycle of forming unit or the root-mean-square value, which is determined by the dependence:

$$
\begin{aligned}
& \overline{M_{i}}=\sqrt{\frac{1}{t_{1}} \int_{0}^{t_{1}} m^{2} \cdot \dot{\varphi}^{4}\left(\frac{\partial x_{1}}{\partial \varphi} \frac{\partial^{2} x_{1}}{\partial \varphi^{2}}+\frac{\partial x_{2}}{\partial \varphi} \frac{\partial^{2} x_{2}}{\partial \varphi^{2}}+\frac{\partial x_{3}}{\partial \varphi} \frac{\partial^{2} x_{3}}{\partial \varphi^{2}}+\frac{\partial x_{4}}{\partial \varphi} \frac{\partial^{2} x_{4}}{\partial \varphi^{2}}\right)^{2} \mathrm{~d} t}= \\
& =m \cdot \sqrt{\frac{1}{t_{1}} \int_{0}^{t_{1}} \dot{\varphi}^{4} \cdot\left(\frac{\partial x_{1}}{\partial \varphi} \frac{\partial^{2} x_{1}}{\partial \varphi^{2}}+\frac{\partial x_{2}}{\partial \varphi} \frac{\partial^{2} x_{2}}{\partial \varphi^{2}}+\frac{\partial x_{3}}{\partial \varphi} \frac{\partial^{2} x_{3}}{\partial \varphi^{2}}+\frac{\partial x_{4}}{\partial \varphi} \frac{\partial^{2} x_{4}}{\partial \varphi^{2}}\right)^{2} \mathrm{~d} t .}
\end{aligned}
$$

The torque imbalance from the inertia forces action can also be estimated by the dimensionless coefficient. We present its by the root-mean-square values ratio of the inertia moment for the whole mechanism and the inertia moment components of the individual elements for the roller forming unit. This coefficient has the form:

$$
\begin{aligned}
& k_{M_{i}}=\sqrt{\frac{1}{t_{1}} \int_{0}^{t_{1}} \frac{\dot{\varphi}^{4} \cdot\left(\frac{\partial x_{1}}{\partial \varphi} \frac{\partial^{2} x_{1}}{\partial \varphi^{2}}+\frac{\partial x_{2}}{\partial \varphi} \frac{\partial^{2} x_{2}}{\partial \varphi^{2}}+\frac{\partial x_{3}}{\partial \varphi} \frac{\partial^{2} x_{3}}{\partial \varphi^{2}}+\frac{\partial x_{4}}{\partial \varphi} \frac{\partial^{2} x_{4}}{\partial \varphi^{2}}\right)^{2}}{\left.\dot{\varphi}^{4}\left(\frac{\partial x_{1}}{\partial \varphi} \frac{\partial^{2} x_{1}}{\partial \varphi^{2}}\right)^{2}+\dot{\varphi}^{4}\left(\frac{\partial x_{2}}{\partial \varphi} \frac{\partial^{2} x_{2}}{\partial \varphi^{2}}\right)^{2}+\right]}} \mathrm{d} t= \\
& =\sqrt{\left.\left.\frac{1}{4} \cdot \frac{\partial x_{3}}{\partial \varphi} \frac{\partial^{2} x_{3}}{\partial \varphi^{2}}\right)^{2}+\dot{\varphi}^{4}\left(\frac{\partial x_{4}}{\partial \varphi} \frac{\partial^{2} x_{4}}{\partial \varphi^{2}}\right)^{2}\right]} \frac{\left(\frac{\partial x_{1}}{\partial \varphi} \frac{\partial^{2} x_{1}}{\partial \varphi^{2}}+\frac{\partial x_{2}}{\partial \varphi} \frac{\partial^{2} x_{2}}{\partial \varphi^{2}}+\frac{\partial x_{3}}{\partial \varphi} \frac{\partial^{2} x_{3}}{\partial \varphi^{2}}+\frac{\partial x_{4}}{\partial \varphi} \frac{\partial^{2} x_{4}}{\partial \varphi^{2}}\right)^{2}}{\left.\frac{\partial x_{1}}{\partial \varphi} \frac{\partial^{2} x_{1}}{\partial \varphi^{2}}\right)^{2}+\left(\frac{\partial x_{2}}{\partial \varphi} \frac{\partial^{2} x_{2}}{\partial \varphi^{2}}\right)^{2}+\left(\frac{\partial x_{3}}{\partial \varphi} \frac{\partial^{2} x_{3}}{\partial \varphi^{2}}\right)^{2}+\left(\frac{\partial x_{4}}{\partial \varphi} \frac{\partial^{2} x_{4}}{\partial \varphi^{2}}\right)^{2}} \mathrm{~d} t .
\end{aligned}
$$

The roller forming unit with balanced drive has the following parameters $[16,18]: \quad m_{1}=m_{2}=m_{3}=m_{4}=m=1000 \mathrm{~kg} ; \quad r=0,2 \mathrm{~m} ; \quad l=0,8 \mathrm{~m}$; $J_{d r}=72,92 \mathrm{~kg} \cdot \mathrm{m}^{2} ; \omega_{o}=104,72 \mathrm{rad} / \mathrm{s} ; \omega_{\text {nom }}=102,1 \mathrm{rad} / \mathrm{s} ; \omega_{\text {crit }}=94,95 \mathrm{rad} / \mathrm{s} ;$ $M_{\text {crit }}=517,14 \mathrm{~N} \cdot \mathrm{m} ; \quad s_{\text {crit }}=0,0933 ; \quad u=9,8 ; \quad \eta=0,9 ; \quad F_{\text {res } 1}=3562 \mathrm{~N} ;$ $F_{\text {res } 2}=3562 \mathrm{~N} ; \quad F_{\text {res } 3}=3562 \mathrm{~N} ; F_{\text {res } 4}=3562 \mathrm{~N}$. We determined the total inertia force $F_{i c}$ and torque $M_{i}$ values from the inertia forces action in one cycle $(0 \leq \varphi \leq 2 \pi)$, which showed in the graphic dependences form (Fig. 2).

The graphic dependences of the total in ertia force $F_{i c}$ and torque $M_{i}$ from the inertia forces action in one cycle $(0 \leq \varphi \leq 2 \pi)$ at different values of the cranks displacement angle $\left(0^{\circ}, 30^{\circ}, 45^{\circ}, 60^{\circ}\right)$ areshownin Fig. 3 and 4. 


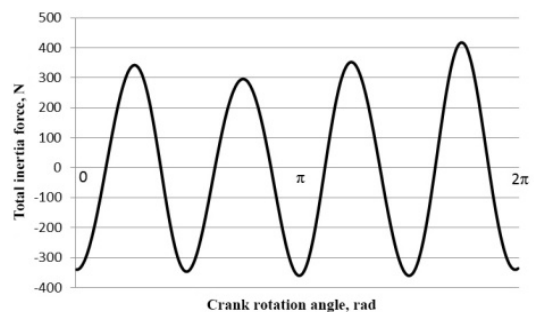

(a)

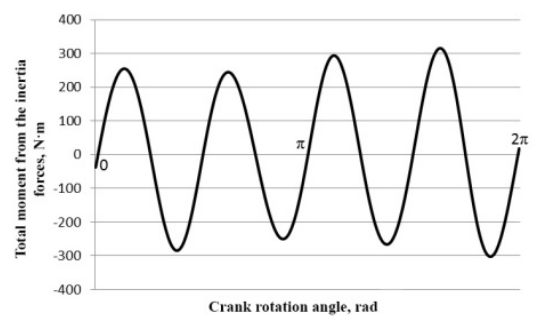

(b)

Fig. 2. Graphic dependences of the total inertia force (a) and the total moment fromthe inertia forces (b) on the crank rotation angle of unit with balanced drive

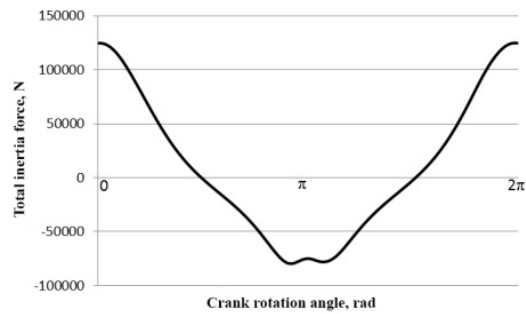

(a)

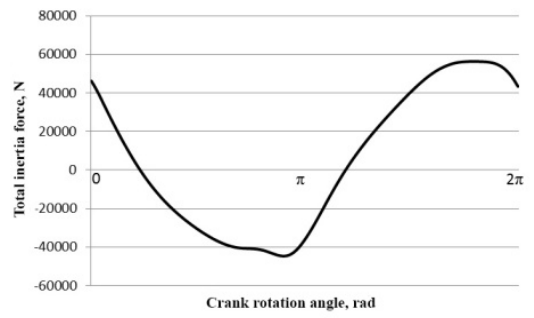

(c)

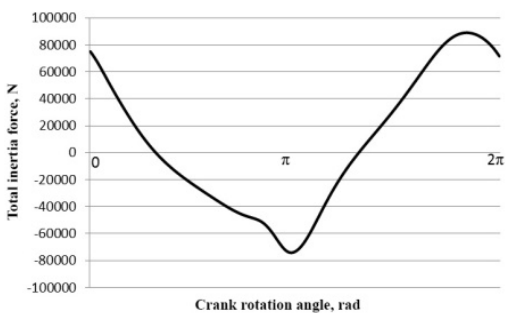

(b)

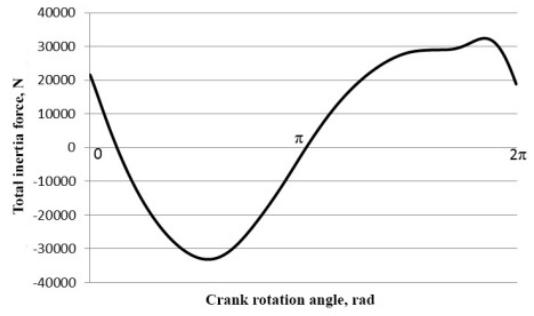

(d)

Fig. 3. Graphic dependences of the total inertia force for unit with balanced driveon the crank rotation angle at different values of the cranks displacement angle $\Delta \varphi: \mathrm{a}-0^{\circ} ; \mathrm{b}-30^{\circ} ; \mathrm{c}-45^{\circ} ; \mathrm{d}-60^{\circ}$

The maximum $F_{i c \max }$ and $M_{i \max }$, and root-mean-square $\bar{F}_{i c}$ and $\overline{M_{i}}$ values of the inertia forces and moments from inertia forces at different angle $\Delta \varphi$ are also found. The calculations results, and dimensionless coefficients values $k_{F_{i}}$ and $k_{M_{i}}$, which are determined by equations (23) and (27), are listed in Table 1. According to the table data, we constructed the graphic dependences of the maximum $F_{i c \max }$ and $M_{i \max }$, and root-mean-square $\bar{F}_{i c}$ and $\overline{M_{i}}$ values of the inertia forces and moments from inertia forces at different values of the cranks displacement angle $\Delta \varphi$ (Fig. 5 and 6). 


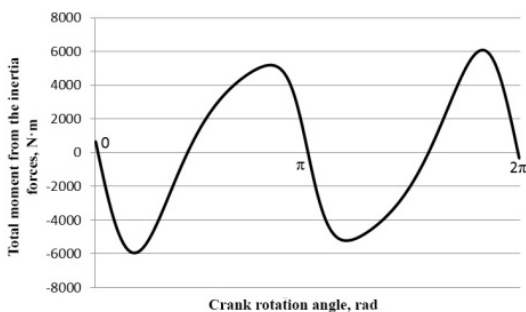

(a)

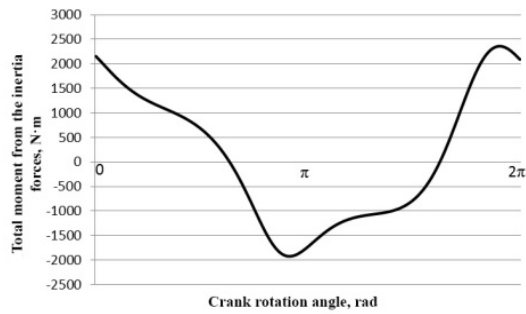

(c)

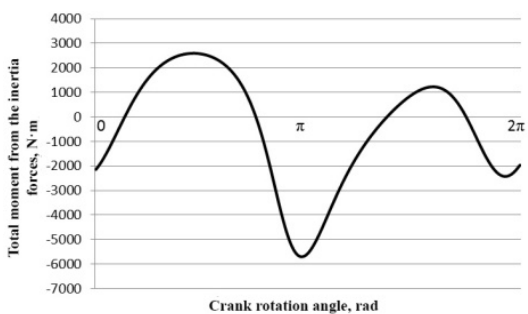

(b)

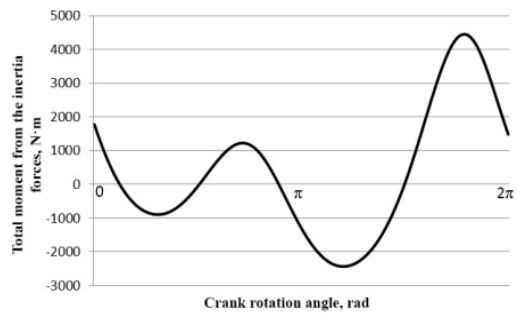

(d)

Fig. 4. Graphic dependences of the total moment from the inertia forces for unit withbalanced drive on the crank rotation angle at different values of the cranksdisplacement angle $\Delta \varphi: \mathrm{a}-0^{\circ} ; \mathrm{b}-30^{\circ}$; $c-45^{\circ} ; \mathrm{d}-60^{\circ}$

The maximum $F_{i c \max }$ and $M_{i \max }$, and root-mean-square $\bar{F}_{i c}$ and $\overline{M_{i}}$ values of the inertia forces and moments from inertia forces at different angle $\Delta \varphi$ are also found. The calculations results, and dimensionless coefficients values $k_{F_{i}}$ and $k_{M_{i}}$, which are determined by equations (23) and (27), are listed in Table 1. According to the table data, we constructed the graphic dependences of the maximum $F_{i c \max }$ and $M_{i \max }$, and root-mean-square $\bar{F}_{i c}$ and $\overline{M_{i}}$ values of the inertia forces and moments from inertia forces at different values of the cranks displacement angle $\Delta \varphi$ (Fig. 5 and 6).

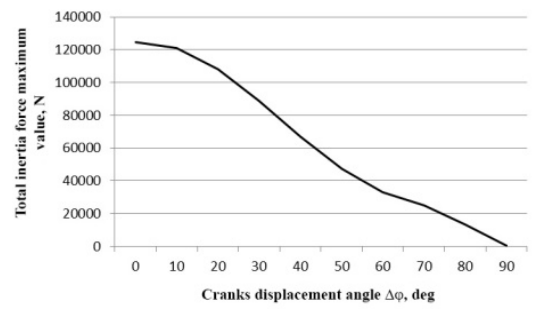

(a)

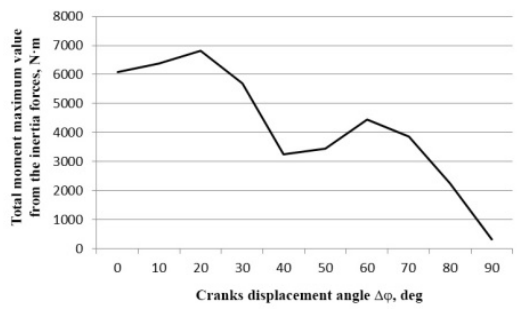

(b)

Fig. 5. Graphicdependencesofthetotal inertia force $F_{i c \max }$ (a) and total moment maximumvalues from the inertia forces $M_{i \max }$ (b) on the cranksdisplacement angle $\Delta \varphi$ 
Fig. 7 presents graphic dependences ofthe dimensionless coefficients $k_{F_{i}}$ and $k_{M_{i}}$ on the cranks displacement angle $\Delta \varphi$.

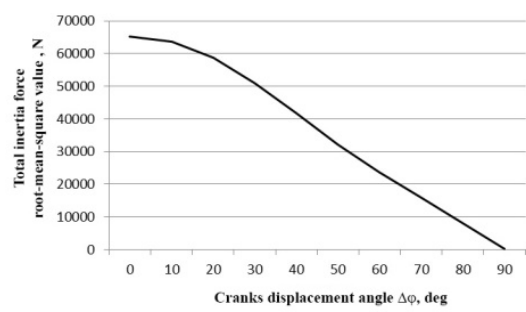

(a)

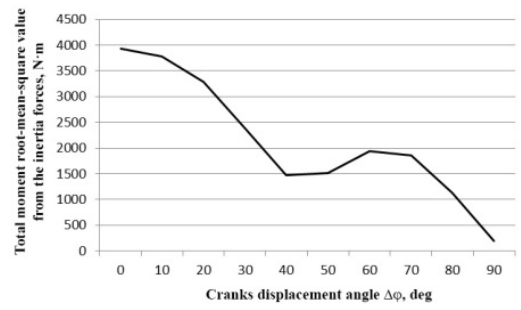

(b0

Fig. 6. Graphicdependencesofthe total inertia force $\bar{F}_{i c}$ (a) and total moment root-mean-square values from the inertia forces $\overline{M_{i}}$ (b) on the cranksdisplacement angle $\Delta \varphi$

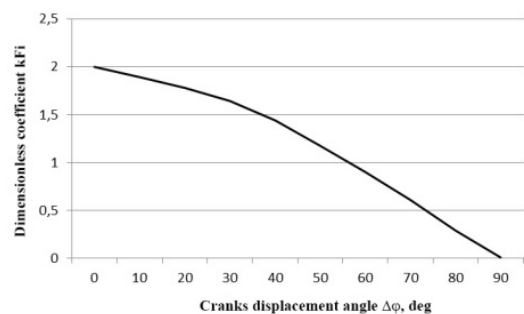

(a)

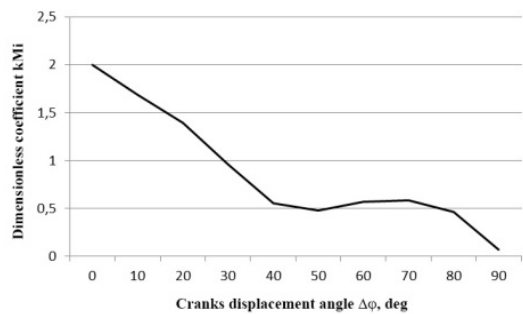

(b)

Fig. 7. Graphicdependencesofthe dimensionless coefficients $k_{F_{i}}$ (a) and $k_{M_{i}}$ (b) on the cranksdisplacement angle $\Delta \varphi$

Table 1

\begin{tabular}{|c|c|c|c|c|c|c|}
\hline$\Delta \varphi,^{\circ}$ & $F_{i c \max }, \mathrm{N}$ & $M_{i \max }, \mathrm{N} \cdot \mathrm{m}$ & $\bar{F}_{i c}, \mathrm{~N}$ & $\overline{M_{i}}, \mathrm{~N} \cdot \mathrm{m}$ & $k_{F_{i}}$ & $k_{M_{i}}$ \\
\hline 0 & 124688,7 & 6088,3 & 65201,03 & 3933,8 & 2 & 2 \\
\hline 10 & 120946,5 & 6384,8 & 63602,25 & 3786,15 & 1,889 & 1,6844 \\
\hline 20 & 108189,7 & 6823,7 & 58718,26 & 3289,36 & 1,7767 & 1,3913 \\
\hline 30 & 88956,1 & 5703,5 & 51037,04 & 2381,85 & 1,639 & 0,9598 \\
\hline 40 & 66994,04 & 3251,8 & 41688,26 & 1469,99 & 1,4398 & 0,5565 \\
\hline 50 & 47329,63 & 3441,9 & 32217,75 & 1509,82 & 1,1711 & 0,4773 \\
\hline 60 & 33138,5 & 4453,2 & 23669,64 & 1939,24 & 0,8985 & 0,5683 \\
\hline 70 & 25178,1 & 3864,8 & 15862,5 & 1849,7 & 0,6084 & 0,5859 \\
\hline 80 & 13490,7 & 2236,9 & 8021,3 & 1124,9 & 0,287 & 0,4623 \\
\hline 90 & 417,7 & 315,7 & 249,3 & 196,2 & 0,00792 & 0,0661 \\
\hline
\end{tabular}


The angular velocity $\dot{\varphi}$ of the drive shaft and its angular acceleration $\ddot{\varphi}$ for each value of the cranks displacement angle $\Delta \varphi$, determined by the method [16], were used to determine the above characteristics of the forming unit.

The analysis of the table data and the graphic dependences (Fig. 5-7) shows that:

- the total inertia force maximum value $F_{i c \max }$, the total inertia force rootmean-square value $\bar{F}_{i c}$ and the dimensionless coefficient $k_{F_{i}}$ are constantly reduced when increase the cranks displacement angle and accepted the minimum value when the cranks displacement $\Delta \varphi=90^{\circ}$;

- the moment maximum value from the inertia forces $M_{i \max }$ on first increases at the cranks displacement angle values from $\Delta \varphi=0^{\circ}$ to $\Delta \varphi=20^{\circ}$, then decreases at the cranks displacement angle values from $\Delta \varphi=20^{\circ}$ to $\Delta \varphi=40^{\circ}$, then there is a slight increase the cranks displacement angle from $\Delta \varphi=40^{\circ}$ to $\Delta \varphi=60^{\circ}$, and then decreases again and acquire minimum value at $\Delta \varphi=90^{\circ}$;

- the moment root-mean-square value from the inertia forces $\overline{M_{i}}$ and the dimensionless coefficient $k_{M_{i}}$ decrease at the cranks displacement angle values from $\Delta \varphi=0^{\circ}$ to $\Delta \varphi=40^{\circ}\left(\overline{M_{i}}\right)$ and $\Delta \varphi=50^{\circ}\left(k_{M_{i}}\right)$, then they increase to the cranks displacement angle values $\Delta \varphi=60^{\circ}\left(\overline{M_{i}}\right)$ and $\Delta \varphi=70^{\circ}\left(k_{M_{i}}\right)$, and then decrease and acquire minimum value at $\Delta \varphi=90^{\circ}$.

Conclusions.As a result of researches, the dynamic balancing of the drive mechanism for the roller forming unit with balanced drive is considered. Two dynamic balancing problems are solved in the simulation process of the drive mechanism balancing for the roller forming machines: the inertia forces balancing which applied in the masses centers of the motion links, and the torque balancing which reduced to rotation axis of the drive shaft, that arise from the inertia forces action. It is established that the best balancing of the inertia forces applied in the masses centers of motion links, and the torque balancing which reduced to rotation axis of the drive shaft, that arise from the inertia forces action, are observed at the cranks displacement angle value $\Delta \varphi=90^{\circ}$ for the roller forming unit with balanced drive. The work results may in the future are used to refine and improve the existing engineering methods for estimating the drive mechanisms of roller forming machines, both at design stages and in practical use.

\section{REFERENCES}

1. Harnets V. M. Prohresyvni betonoformuiuchi ahrehaty I kompleksy (Progressive concreteforming units and complexes). Kyiv: Budivelnyk, 1991. 144 p. [in Ukrainian]. 
2. Harnets V.M., Zaichenko S. V., Chovniuk Yu. V., Shalenko V. O., PrykhodkoYa. S. Betonoformuvalni ahrehaty. Konstruktyvno-funktsionalni skhemy, pryntsyp dii, osnovyteorii: Monohrafiia (Concrete-forming units. Structural and functional schemes, operation principle, theory basics: Monograph). Kyiv: Interservis, 2015. 238 p. [in Ukrainian].

3. Kuzin V.N. Tehnologija rolikovogo formovanija ploskih izdelij iz melkozernistyh betonov (Roller forming technology of flat products from fine-grained concrete: Extended abstract of candidate's thesis). Moscow, 1981.20 p. [in Russian].

4. Rjushin V.T. Issledovanie rabochego processa I razrabotka metodiki rascheta mashin rolikovogo formovanija betonnyh smesej (Working process research and methodology development of calculating machines for concrete mixtures roller forming: Extended abstract of candidate's thesis). Kyiv, 1986.20 p. [in Russian].

5. Loveikin V.S., Pochka K. I. Dynamichnyi analiz rolykovoi formovochnoi ustanovky z rekuperatsiinym pryvodom (Dynamic analysis of roller forming unit with recuperative drive). Dynamika, mitsnist I nadiinist silskohospodarskykh mashyn: materialy pershoi Mizhnarodnoi naukovo-tekhnichnoi konferentsii (Dynamics, Strength and Reliability of Agricultural Machinery: Proceedings of the 1st International Scientific and Technical Conference (DSR AM-I). Ternopil, 2004. P. 507-514 (in Ukrainian).

6. Nazarenko I. I., Smirnov V. M., Pelevin L. Ye., Fomin A. V., Sviderskyi A. T., Kosteniuk O. O., Ruchynskyi M. M., Diedov O. P., Harkavenko O. M., Martyniuk I. Yu. Osnovy teorii rukhu zemleryinykh I uschilniuvalnykh mashyn budindustrii z kerovanymy u chasi optymalnymy parametramy: Monohrafiia (Motion theory fundamentals of earthmoving and compaction machines for building industry with time-controlled optimal parameters: Monograph). Kyiv: MP Lesia, 2013. 188 p. (in Ukrainian).

7. Zaichenko S., Shalenko V., Shevchuk N., VapnichnaV. Development of a geomekhanic complex for geotechnical monitoring contour mine groove. Eastern-European Journal of Enterprise Technologies. 2017. Vol. 3/9 (87). P. 19-25. DOI: 10.155/17294061.2017.102067.

8. Harnets V. M., Chovniuk Yu. V., Zaichenko S. V., Shalenko V. O., Prykhodko Ya. S. Teoriia i praktyka stvorennia betonoformuvalnykh ahrehativ (BFA) (Theory and practice of creating concrete-forming units). Hirnychi, budivelni, dorozhni ta melioratyvnimashyny. 2014. Issue 83. P. 49-54 (in Ukrainian).

9. Harnets V.M., Zaichenko S. V., PrykhodkoYa.S., Shalenko V.O. Rozrobkanaukovopraktychnykhrekomendatsiipostvorenniubetonoformuiuchykhahrehativ (BFA) (Development of scientific and practical recommendations for the creation of concrete-forming). Hirnychi, budivelni, dorozhni ta melioratyvnimashyny. 2012. Issue 79. P. 46-52 (in Ukrainian).

10. Zaichenko S. V., Shevchuk S.P., Harnets V.M. Enerhetychnyianalizprotsesurolykovohouschilnennia (Energy analysis of the roller compaction process). Enerhetyka: Ekonomika, tekhnolohiia, ekolohiia. 2012. Vol. 1 (30). P. 77-83 (in Ukrainian).

11. Zaichenko S. V., Shevchuk S.P., Harnets V.M. Tryvymirne modeliuvannia protsesu rolykovoho uschilnennia stovburnoho kriplennia (Three-dimensional modeling of roller compaction process of the trunk). Hirnychi, budivelni, dorozhni ta melioratyvnimashyny. 2012. Issue 79. P. 40-45 (in Ukrainian).

12. PrykhodkoYa.S., Harnets V.M. Vzaiemouzghodzhenist roboty mekhanizmiv pry rolykoekstruziinomu formuvanni bahatopustotnykh vyrobiv (Mutual coherence of mechanisms in roller-extrusion forming of multi-hollow products). Haluzevemashynobuduvannia, budivnytstvo. 2012. Vol. 1 (31). P. 305-310. (in Ukrainian).

13. Loveikin V. S., Pochka K. I., Romasevych Yu. O., Pochka O. B. Dynamichnyi analiz rolykovoi formuvalnoi ustanovky z kryvoshypno-shatunnym pryvidnym mekhanizmom (Dynamic analysis of roller forming unit with crank drive mechanism). Strength of Materials and Theory of Structures. 2019. Issue 102. P. 91-108. DOI: 10.32347/2410-2547.2019.102.91-108 (in Ukrainian).

14. Loveikin V. S., Pochka K. I., Prystailo M. O., Pochka O. B. Dynamichne zrivnovazhennia pryvidnoho mekhanizmu rolykovoi formuvalnoi ustanovky z enerhetychno vrivnovazhenym pryvodom (Drive mechanism dynamic balancing of roller forming unit with energy-balanced drive). Strength of Materials and Theory of Structures. 2019. Issue 103. P. 112-130. DOI: 10.32347/2410-2547.2019.103.112-130 (in Ukrainian). 
15. Loveikin V.S., Pochka K.I. Sintez kulachkovogo privodnogo mehanizma rolikovoj formovochnoj ustanovki s kombinirovannym rezhimom dvizhenija po uskoreniju tret'ego porjadka (Synthesis of a cam drive mechanism for roller forming unit with combined thirdorder acceleration mode). Naukaitehnika. Minsk, 2017. Vol. 16 (3). P. 206-214. DOI: 10.21122/2227-1031-2017-16-3-206-214 (in Russian).

16. Loveikin V.S., Pochka K.I. Analiz neravnomernosti dvizhenija rolikovoj formovochnoj ustanovki s uravnoveshennym privodom (Motion non-uniformity analysis of roller forming unit with balanced drive). MOTROL. Commission of Motorization and Energetics in Agriculture. Lublin-Rzeszow, 2015. Vol. 17, No 3. P. 17-27 (in Russian).

17. Loveikin V. S., Pochka K. I., Prystailo M. O.,Balaka M. M., Pochka O. B. Impact of cranks displacement angle on the motion non-uniformity of roller forming unit with energy-balanced drive. Strength of Materials and Theory of Structures. 2021. Issue 106. P. 141-155. DOI: 10.32347/2410-2547.2021.106.141-155.

18. Loveikin V.S., Pochka K.I. Analiz rukhu rolykovoi formovochnoi ustanovky $\mathrm{z}$ vrivnovazhenym pryvodom (Motion analysis of roller forming unit with balanced drive). Bulletin of Kharkov National Automobile and Highway University. 2004. Issue 27. P. 95-101 (in Ukrainian).

19. Pat. 32838 U Ukraine, IPC B28B 13/00. Ustanovka dlia formuvannia vyrobiv z betonnykh sumishei (Forming unit for products from concrete mixtures) / Loveikin V. S., Yaroshenko V. F., Pochka K. I. Publ. 10.06.2008 (in Ukrainian).

20. Pat. 7884 U Ukraine, IPC B28B 13/00. Ustanovka dlia formuvannia vyrobiv z betonnykh sumishei (Forming unit for products from concrete mixtures) / Loveikin V. S., Yaroshenko V. F., Pochka K. I., Bychevskyi V. M. Publ. 15.07.2005 (in Ukrainian).

Стаття надійшла до редакиії 20.05.2021

\section{Ловейкін В. С., Почка К. І., Пристайло М. О., Балака М. М., Почка О. Б. ДИНАМІЧНЕ ЗРІВНОВАЖЕННЯ ПРИВОДУ РОЛИКОВОЇ ФОРМУВАЛЬНОЇ УСТАНОВКИ}

3 метою підвищення надійності та довговічності розглянуто динамічне зрівноваження привідного механізму роликової формувальної установки з врівноваженим приводом. При моделюванні процесу зрівноваження привідного механізму розв'язано дві задачі динамічного врівноваження: врівноваження сил інерції, що прикладені в центрах мас рухомих ланок, та врівноваження приведеного до осі обертання привідного вала крутного моменту, що виникає від дії сил інерції. При цьому визначено всі кінематичні характеристики формувальних візків установки, записано функції зміни кінетичної енергії кожного елемента установки та всієї системи, сил інерції кожного елемента установки та сумарної сили інерції, сумарного моменту від дії сил інерції. На основі рівнянь Лагранжа другого роду складено рівняння руху установки і визначено узагальнену силу та рушійний момент на валу привідного двигуна. Неврівноваженість привідного механізму оцінюється максимальними і середньоквадратичними значеннями сумарної сили інерції та сумарного крутного моменту від дії сил інерції, безрозмірними коефіцієнтами, що виражають відношення середньоквадратичних значень зведених до центру мас установки сумарної сили інерції та сил інерції, що діють на кожний візок, і відношення середньоквадратичних значень моменту від дії сил інерції всього механізму і складових моменту від дії сил інерції окремих елементів. Встановлено, що в установці з врівноваженим приводом найкраще врівноваження сил інерції, що прикладені в центрах рухомих мас ланок, та приведеного до осі обертання привідного валу крутного моменту, що виникає від дії сил інерції, спостерігається при значенні кута зміщення кривошипів $\Delta \varphi=90^{\circ}$. Отримані результати можуть бути у подальшому використані для уточнення та вдосконалення існуючих інженерних методів розрахунку привідних механізмів машин роликового формування як на стадіях проєктування, так і у режимах реальної експлуатації.

Ключові слова: роликова формувальна установка, привідний механізм, сила інерції, момент, зрівноваження. 


\section{Loveikin V. S., Pochka K. I., Prystailo M. O., Balaka M. M., Pochka O. B. \\ DYNAMIC BALANCING OF ROLLER FORMING UNIT DRIVE}

The dynamic balancing of the drive mechanism for the roller forming unit with balanced drive is consideredin order to increase reliability and durability. Two dynamic balancing problems are solved in the simulation process of the drive mechanism balancing: the inertia forces balancing which applied in the masses centers of the motion links, and the torque balancing which reduced to rotation axis of the drive shaft, that arise from the inertia forces action. Wherein all kinematic characteristics of the unit forming trolleys are determined, the change functions of the kinetic energy for the unit each element and whole system, the inertia forces of the unit each element and the total inertia force, the total moment from the inertia forces action are written. The unit motion equation is compiled based on the Lagrange equations of the second-order, and the generalized force and moment on the drive motor shaft are determined.The drive mechanism imbalance is estimated by the maximum and root-mean-square values of the total inertia forceand total torque from the inertia forces action, the dimensionless coefficients, which express the root-mean-square values ratio of the total inertia force and inertia forces, that act on each trolley, and the root-meansquare values ratio of the moment from the inertia forces action of the whole mechanism and moment components from the inertia forces action of the individual elements.It is established that the best balancing of the inertia forces applied in the masses centers of motion links, and the torque balancing which reduced to rotation axis of the drive shaft, that arise from the inertia forces action, are observed at the cranks displacement angle value $\Delta \varphi=90^{\circ}$ for the roller forming unit with balanced drive. The work results may in the future are used to refine and improve the existing engineering methods for estimating the drive mechanisms of roller forming machines, both at design stages and in practical use.

Keywords:roller forming unit, drive mechanism, inertia force, moment, balancing.

\section{Ловейкин В. С., Почка К. И., Пристайло Н. А., Балака М. Н., Почка О. Б. \\ ДИНАМИЧЕСКОЕ УРАВНОВЕШИВАНИЕ ПРИВОДА РОЛИКОВОЙ ФОРМОВОЧНОЙ УСТАНОВКИ}

С целью повышения надёжности и долговечности рассмотрено динамическое уравновешивание приводного механизма роликовой формовочной установки $\mathrm{c}$ уравновешенным приводом. При моделировании процесса уравновешивания приводного механизма решено две задачи динамического уравновешивания: уравновешивание сил инерции, приложенных в центрах масс подвижных звеньев, и уравновешивание приведенного к оси вращения приводного вала крутящего момента, возникающего от действия сил инерции. При этом определены все кинематические характеристики формовочных тележек установки, записаны функции кинетической энергии каждого элемента и всей системы, сил инерции каждого элемента установки и суммарной силы инерции, суммарного момента от действия сил инерции. На основании уравнений Лагранжа второго рода составлено уравнение движения установки и определены обобщённая сила и движущий момент на валу приводного двигателя. Неуравновешенность приводного механизма оценивается максимальными и среднеквадратическими значениями суммарной силы инерции и суммарного крутящего момента от действия сил инерции, безразмерными коэффициентами, выражающими отношение среднеквадратических значений приведенных к центру масс установки суммарной силы инерции и сил инерции, действующих на каждую тележку, и отношение среднеквадратических значений момента от действия сил инерции всего механизма и составляющих момента от действия сил инерции отдельных элементов. Установлено, что в установке с уравновешенным приводом наилучшее уравновешивание сил инерции, приложенных в центрах масс звеньев, и приведенного к оси вращения приводного вала крутящего момента, возникающего от действия сил инерции, наблюдается при значении угла смещения кривошипов $\Delta \varphi=90^{\circ}$. Полученные результаты могут быть в дальнейшем использованы для уточнения и усовершенствования существующих инженерных методов расчёта приводных механизмов машин роликового формования как на стадиях проектирования, так и в режимах реальной эксплуатации.

Ключевые слова: роликовая формовочная установка, приводной механизм, сила инерции, момент, уравновешивание. 


\section{УДК 693.546}

Ловейкін В.С., Почка К.І., Пристайло М.О., Балака М.М., Почка О.Б. Динамічне зрівноваження приводу роликової формувальної установки // / Опір матеріалів і теорія споруд: наук.-тех. збірн. - К.: КНУБА, 2021. - Вип. 107. - С. 140-158. - Англ.

Для роликової формувальної установки з врівноваженим приводом розглянуто динамічне зрівноваження привідного механізму. Неврівноваженість привідного механізму оцінюється максимальними і середньоквадратичними значеннями сумарної сили інериії та сумарного крутного моменту від дії сил інериії, безрозмірними коефіцієнтами, що виражають відношення середньоквадратичних значень зведених до центру мас установки сумарної сили інериї̈ та сил інериїі, що діють на кожний візок, і відношення середньоквадратичних значень моменту від дії сил інериї всього механізму і складових моменту від дії сил інериії окремих елементів.

Табл. 1. Іл. 7. Бібліогр. 20 назв.

\section{UDC693.546}

Loveikin V. S., Pochka K. I., Prystailo M. O., Balaka M. M., Pochka O. B. Dynamic balancing of roller forming unit drive// Strength of Materials and Theory of Structures: Scientific-andtechnical collected articles. - K.: KNUBA, 2021. - Issue 107. - P. 140-158.

The dynamic balancing of the drive mechanism is considered for the roller forming unit with balanced drive. The drive mechanism imbalance is estimated by the maximum and root-meansquare values of the total inertia forceand total torque from the inertia forces action, the dimensionless coefficients, which express the root-mean-square values ratio of the total inertia force and inertia forces, that act on each trolley, and the root-mean-square values ratio of the moment from the inertia forces action of the whole mechanism and moment components from the inertia forces action of the individual elements.

Table 1.Fig. 7.Ref. 20.

\section{УДК 693.546}

Ловейкин В. С., Почка К. И., Пристайло Н. А., Балака М. Н., Почка О. Б. Динамическое уравновешивание привода роликовой формовочной установки// Сопротивление материалов и теория сооружений: науч.-тех. сборн. - К.: КНУСА, 2021. - Вип. 107. - С. 140 158. - Англ.

Для роликовой формовочной установки с уравновешенным приводом рассмотрено динамическое уравновешивание приводного механизма. Неуравновешенность приводного механизма оценивается максимальными и среднеквадратическими значениями суммарной силь инериии исуммарного крутящего момента от действия сил инериии, безразмерными коэффициентами, выражающими отнотение среднеквадратических значений приведенных к иентру масс установки суммарной силь инериии и сил инериии, действующих на каждую тележку, и отношение среднеквадратических значений момента от действия сил инерции всего механизма и составляюших момента от действия сил инериии отдельных элементов. Табл. 1. Ил. 7. Библиогр. 20 назв.

Автор (вчена ступень, вчене звання, посада): доктор технічних наук, професор, завідувач кафедри конструювання машин $і$ обладнання Національного університету біоресурсів $i$ природокористування Украӥни ЛОВЕЙКІН Вячеслав Сергійович

Адреса робоча: 03041, Украӥна, м. Київ, вул. Героӥв Оборони, 12, навчальний корпус № 11, Національний університет біоресурсів $і$ природокористування Украӥни, кафедра конструювання машин і обладнання, ЛОВЕЙКІНУ Вячеславу Сергійовичу

Робочий тел.: +38(044) 527-87-34;

Мобільний тел.: +38(097) 349-14-53;

E-mail:lovvs@ukr.net

ORCID ID: https://orcid.org/0000-0003-4259-3900 
Автор (вчена ступень, вчене звання, посада): доктор технічних наук, професор, завідувач кафедри професійної освіти КНУБА ПОЧКА Костянтин Іванович

Адреса робоча: 03037, Украӥна, м. Київ, Повітрофлотський проспект 31, Київський національний університет будівництва і архітектури, кафедра професійної освіти, ПОЧЦІ

Костянтину Івановичу

Робочий тел.: +38(044) 248-69-25;

Мобільний тел.: +38(097) 212-86-29;

E-mail:shanovniy@ukr.net

ORCID ID: https://orcid.org/0000-0002-0355-002X

Автор (вчена ступень, вчене звання, посада): кандидат технічних наук, доцент, доцент кафедри будівельних машин КНУБА ПРИСТАЙЛО Микола Олексійович

Адреса робоча: 03037, Украӥна, м. Київ, Повітрофлотський проспект 31, Київський національний університет будівництва $i$ архітектури, кафедра будівельних машин, ПРИСТАЙЛУ Миколі Олексійовичу

Мобільний тел.: +38(097) 495-07-50;

E-mail:pristaylo na@ukr.net

ORCID ID: https://orcid.org/0000-0003-3151-4680

Автор (вчена ступень, вчене звання, посада): кандидат технічних наук, доцент кафедри будівельних машин КНУБА БАЛАКА Максим Миколайович

Адреса робоча: 03037, Украӥна, м. Київ, Повітрофлотський проспект 31, Київський національний університет будівництва $i$ архітектури, кафедра будівельних машин, БАЛАЦІ Максиму Миколайовичу

Мобільний тел.: +38(067) 995-53-89;

E-mail: balaka.mm@knuba.edu.ua

ORCID ID: https://orcid.org/0000-0003-4142-9703

Автор (вчена ступень, вчене звання, посада): асистент кафедри теплогазопостачання $i$ вентиляиії КНУБА ПОЧКА Ольга Богданівна

Адреса робоча: 03037, Украӥна, м. Київ, Повітрофлотський проспект 31, Київський національний університет будівництва $i$ архітектури, кафедра теплогазопостачання $i$ вентиляції, ПОЧЦІ Ользі Богданівні

Мобільний тел.: +38(097) 196-92-04;

E-mail:zasedkoolga@ukr.net

ORCID ID: https://orcid.org/0000-0001-5701-978X 